\title{
Pengaruh Outer Membrane Protein Helicobacter Pylori terhadap Perubahan Histopatologi Mukosa Lambung dan S-IgA pada Mus musculus Outbred Balb/C
}

\author{
Yuniati $^{1 *}$, Harijono Achmad ${ }^{2}$, Sumarno ${ }^{2}$ \\ ${ }^{1}$ Program Studi Pendidikan Dokter, Fakultas Kedokteran, Universitas Mulawarman, Samarinda \\ Program Studi Biomedik, Program Pascasarjana Fakultas Kedokteran, Universitas Brawijaya, Malang
}

\begin{abstract}
Abstrak
Helicobacter pylori (H. pylori) merupakan bakteri penyebab inflamasi mukosa lambung. Faktor virulensi bakteri berperan pada patogenesis penyakit infeksi oleh bakteri yang pada umumnya dapat merangsang sistem imun. Secara umum antigen yang merupakan faktor virulensi ini terdapat dalam Outer Membrane protein (OMP). Pemberian antigen secara per oral mampu menginduksi respon imun mukosal dengan cara membentuk Secretory $\lg A(S-\lg A)$. Penelitian ini bertujuan untuk mengetahui pengaruh OMP H. pylori terhadap histopatologi mukosa lambung Mus musculus Outbred Balb/C dan peningkatan konsentrasi S-IgA pada Mus musculus Outbred Balb/C. Metode Penelitian yang digunakan adalah Post-test only kontrol group design. Bakteri H. pylori dikultur kemudian dilakukan isolasi OMP dengan menggunakan bahan $n$-Octyl- $\beta$-D-Glucopyranoside (NOG) $0,5 \%$ melalui isolasi bertahap dan dilakukan SDS-PAGE. Setelah itu dilakukan coupling dengan CTB dan diberikan ke mencit secara intragastrik dengan dosis $100 \mu \mathrm{gml}^{-1}$ setiap minggu. Pada akhir minggu ke-2, ke-4, ke-6 dan ke-8 dilakukan pemeriksaan histopatologis dan kadar S-lgA. Hasil penelitian menunjukkan terdapat perbedaan yang signifikan $(p<0,05)$ pada perhitungan jumlah sel polimorfonuklear (PMN), jumlah sel Mononuklear (MN) dan kadar S-IgA antara kelompok kontrol dan perlakuan. Berdasarkan hasil penelitian dapat disimpulkan bahwa OMP H. pylori dapat menyebabkan kerusakan mukosa lambung menginduksi S-IgA Mus musculus Outbred Balb/C.
\end{abstract}

Kata Kunci : Helicobacter pylori, $n$-Octyl- $\beta$-D-Glucopyranoside, outer membrane protein (OMP)

\section{PENDAHULUAN}

Pada tahun 1983, Marshall dan Waren berhasil mengisolasi Campylobacter pylori yang sekarang dikenal sebagai Helicobacter pylori $(H$. pylori) dari mukosa lambung penderita gastritis kronis aktif. $H$. pylori telah diterima secara universal sebagai penyebab utama inflamasi mukosa lambung di seluruh dunia dan akhirakhir ini dilaporkan sebagai faktor resiko terjadinya penyakit jantung koroner [1]. H. pylori merupakan organisme penting yang dapat menyebabkan infeksi kronik yang tersebar luas di seluruh dunia. Hampir separuh populasi dunia dewasa dibuktikan secara serologi terinfeksi penyakit ini $[2,3,4]$. Beberapa laporan terbaru menyokong hubungan antara infeksi ini dengan mayoritas penyakit gastrointestinal bagian atas seperti gastritis, ulkus peptik, adenokarsinoma gaster $[3,4,5]$ serta mucosal-associated lymphoid tumor (suatu jenis limfoma gaster) $[5,6,7]$.

\footnotetext{
Alamat korespondensi penulis:

Yuniati

e-mail :yuni_ati@yahoo.com

Alamat : Jl. Krayan Kampus Unmul Gn. Kelua Samarinda, Kalimantan Timur, 75119
}

Diketahui $72 \%-98 \%$ pasien dengan mucosalassociated lymphoid tumor telah terinfeksi $H$. pylori. Kanker gaster merupakan penyebab kematian nomor dua dari seluruh kematian yang disebabkan oleh kanker, dan telah terbukti bahwa $H$. pylori meningkatkan resiko terjadinya kanker gaster [6].

Bukti Helicobacter pylori sebagai patogen gastrointestinal sekarang ini sangat banyak sekali. Sebagai contoh, $H$. pylori telah diisolasi 95\% dari mukosa gaster pasien dengan penyakit ulkus lambung dan $100 \%$ dari pasien dengan gastritis kronik tetapi tidak ditemukan dari jaringan sehat [1]. Hasil penelitian pengujian antiH. pylori dengan metode Passive Haemagglutinin (PHA) di Malang, didapatkan angka prevalensi gastritis kronik pada penderita dispepsia sebesar $90,3 \%$, sedangkan pada kultur mukosa antrum ditemukan bakteri H. pylori sebesar 69\% [8]. Studi yang dilakukan di Korea yang merupakan negara dengan transformasi dari negara non industri menuju negara industri pada dua dekade yang lalu menunjukkan bahwa insiden infeksi $H$. pylori pada dewasa sama dengan negara yang sedang berkembang. Berdasarkan status sosial ekonomi, angka kejadian infeksi $H$. pylori di Korea lebih 
tinggi pada masyarakat ekonomi rendah [9]. Berdasarkan hal tersebut diketahui bahwa potensi kejadian infeksi $H$. Pylori di indonesia besar. Menurut Sanarto, OMP dari Salmonella typhi mampu menginduksi respon imun mukosal protektif dengan cara membentuk Secretory Imunoglobulin-A (S-IgA) membantu penghambatan atau proteksi proses adhesi dan kolonisasi Salmonella typhi pada enterosit mencit [10].

Mekanisme $H$. pylori dalam menyebabkan peradangan dan kerusakan mukosa masih belum dapat dipastikan dan masih sedikit dimengerti $[2,11]$. Beberapa penelitian menyebutkan bahwa bakteri menginvasi sel-sel epitel permukaan sampai batas tertentu. Bakteri menghasilkan toksin dan lipopolisakarida yang dapat merusak sel-sel mukosa, dan dibentuk ammonia oleh aktivitas urease yang secara langsung merusak sel-sel juga [11]. Respon imun terhadap antigen oral berbeda jika dibandingkan respon imun terhadap antigen di tempat lain. Perbedaan utama disebabkan oleh adanya produksi kadar IgA yang tinggi di jaringan mukosa. Imunoglobulin-A ditemukan dalam serum dengan jumlah sedikit tetapi kadarnya dalam cairan sekresi saluran nafas, saluran cerna, saluran kemih, air mata, keringat, ludah dan air susu ibu lebih tinggi dalam bentuk IgA sekretori (S-IgA) [12]. Secretory IgA akan mengikat mikroba dan diperlukan untuk mencegah penempelan mikroorganisme pada epitel serta bersama komplemen diperlukan untuk fagositosis bakteri $H$. pylori sehingga memblokir masuknya $H$. pylori [13]. H. pylori diketahui berada di luar sel mukosa lambung, tetapi OMP $H$. pylori dapat menyebabkan kerusakan di mukosa lambung oleh karena itu perlu diketahui mekanisme kerusakan yang ditimbulkan OMP $H$. pylori terhadap mukosa lambung dan peningkatan konsentrasi S-IgA pada mukosa lambung.

\section{METODE PENELITIAN}

\section{Koleksi Bakteri H. pylori}

H. pylori yang digunakan dalam penelitian ini diperoleh dari penderita gastritis kronik dewasa yang berobat jalan ke Poliklinik Rumah Sakit Umum (RSU) Mataram kemudian dilakukan endoskopi.

\section{Medium Transpor}

Medium transpor yang digunakan adalah medium tioglikolat broth. Medium ini terdiri dari charcoal pharmaceutical neutral $10 \mathrm{~g} \mathrm{I}^{-1}$, sodium chloride $3 \mathrm{~g} \mathrm{I}^{-1}$, sodium hydrogen phosphat 1,15 $\mathrm{g} \mathrm{I}^{-1}$, potassium dihydrogen phosphat $0,2 \mathrm{~g} \mathrm{I}^{-1}$, potassium chloride $0,2 \mathrm{~g} \mathrm{I}^{-1}$, sodium thioglycollate
$1 \mathrm{~g} \mathrm{I}^{-1}$, calcium chloride 0,1 $\mathrm{g} \mathrm{I}^{-1}$, magnesium chloride $0,1 \mathrm{~g} \mathrm{l}^{-1}$ dan $1 \mathrm{~g} \mathrm{l}^{-1}$ agar.

\section{Pewarnaan Gram}

Untuk pewarnaan Gram dibuat sediaan (smear) bakteri pada gelas obyek terlebih dahulu. Sesudah kering di udara, difiksasi dengan panas api lampu spiritus. Kemudian diwarnai dengan urutan sebagai berikut, sediaan dituangi dengan larutan kristal violet, dan didiamkan selama satu menit. Larutan kristal violet dibuang dan dibilas dengan air. Sediaan dituangi dengan lugol, kemudian didiamkan selama satu menit. Kemudian sisa lugol dibuang dan dibilas dengan air. Sediaan dituangi dengan alkohol $96 \%$ selama 5-10 detik atau sampai warna cat luntur. Sisa alkohol dibuang dan dibilas dengan air. Sediaan dituangi dengan Safranin, didiamkan selama 30 detik. Sisa Safranin dibuang dan dibilas dengan air. Selanjutnya sediaan dikeringkan menggunakan kertas penghisap. Sediaan dilihat di bawah mikroskop dengan lensa obyektif perbesaran 100 kali. Bakteri yang tampak berwarna merah dikatakan Gram negatif.

\section{Uji Urease}

Pembuatan media urea adalah sebagai berikut urea Agar Base CM53 ditimbang sebanyak 2,4 g kemudian dilarutkan dengan 95 $\mathrm{ml}$ akuades steril dengan autoklaf $115{ }^{\circ} \mathrm{C}$ selama 20 menit. Setelah suhu media mencapai $50{ }^{\circ} \mathrm{C}$ kemudian ditambah dengan $5 \mathrm{ml}$ urea Oxoid $S R$ 20 40\%. Media selanjutnya dibagikan ke dalam tabung steril lalu dimiringkan.

\section{Uji Oksidase}

Reagen oksidase dibuat dengan melarut-kan $50 \mathrm{mg}$ paraamino dimetil aniline oxalate dalam 5 $\mathrm{ml}$ akuades steril. Reagen oksidase diteteskan dengan menggunakan pipet pada koloni yang dicurigai. Jika terjadi Perubahan warna koloni yang ditetesi menjadi merah menjadi hitam dikatakan uji oksidase positif.

\section{Uji Katalase}

Uji katalase dilakukan dengan medium cair Mueller Hinton yang terdiri dari beef infusion dari $300 \mathrm{~g} \mathrm{I}^{-1}$, casein hydrolysate 17,5 $\mathrm{g} \mathrm{I}^{-1}$, starch 1,5 $\mathrm{g} \mathrm{I}^{-1}$. Sebanyak $25 \mathrm{~g}$ medium Mueller Hinton dilarutkan dalam satu liter air suling. Kemudian dimasukkan ke dalam tabung reaksi masingmasing sebanyak $5 \mathrm{ml}$ tiap tabung reaksi. Kemudian disterilkan dengan autoklaf pada suhu $121{ }^{\circ} \mathrm{C}$ selama 20 menit dan selanjutnya didinginkan pada suhu kamar. Sesudah dingin diuji sterilitasnya dengan cara dieramkan dalam lemari pengeram pada suhu $37{ }^{\circ} \mathrm{C}$ selama semalam. Dilakukan inokulasi bakteri di medium cair Mueller Hinton yang tetap steril. Bakteri 
subyek penelitian ditanam pada medium cair Mueller Hinton dan dieramkan secara mikroaerofilik selama $5 \times 24$ jam pada suhu $37{ }^{\circ} \mathrm{C}$. Pertumbuhan bakteri yang terjadi ditetesi dengan $0,5 \mathrm{ml}$ larutan $\mathrm{H}_{2} \mathrm{O}_{2} 3 \%$ lalu dikocok. Bila timbul gelembung-gelembung gas dari dasar tabung reaksi menuju ke permukaan biakan cair dikatakan uji katalase positif.

Uji Gula

Pengujian glukosa dilakukan dengan melarutkan glukosa 2 g Oxoid L71 dengan air pepton 200 $\mathrm{ml}$, kemudian ditambahkan Endrades $2 \mathrm{ml}$, dan selanjutnya dibagi dalam tabung-tabung serologi Durham. Media tersebut disterilisasi dengan suhu $115{ }^{\circ} \mathrm{C}$ selama 10 menit.

Pengujian laktosa, dilakukan dengan melarutkan sebanyak 2 gram laktosa Oxoid L70 dengan air pepton $200 \mathrm{ml}$, ditambahkan Endrades $2 \mathrm{ml}$. Media kemudian dibagi dalam tabung serologi Durham dan disterilkan pada suhu $115{ }^{\circ} \mathrm{C}$ selama 10 menit.

Pengujian maltosa, dilakukan dengan melarutkan sebanyak 2 gram maltosa BBL 12029 dengan air pepton sebanyak $200 \mathrm{ml}$, kemudian ditambahkan Endrades $2 \mathrm{ml}$. Media selanjutnya dibagi dalam tabung serologi Durham dan disterilkan pada suhu $115^{\circ} \mathrm{C}$ selama 10 menit.

\section{Suasana Mikroaerofilik}

Suasana mikroaerofilik $\left(\mathrm{O}_{2} 5-6 \%, \mathrm{CO}_{2} 8-10 \%\right.$, $\mathrm{N}_{2}$ 80-85\% dan kelembaban relatif 95\%) diperoleh dengan menggunakan gas generating kit BR 38 yang diletakkan di dalam sungkup anaerob. Tiap kantong gas generating kit mengandung tablet natrium borohydrida, asam tertarat dan natrium bikarbonat. Bila ditambahkan $10 \mathrm{ml}$ air ke dalam kantong gas penetrating kit tersebut maka akan dihasilkan $1.800 \mathrm{ml}$ gas $\mathrm{H}_{2}$ dan $350 \mathrm{ml}$ gas $\mathrm{CO}_{2}$.

\section{Hewan Coba}

Penelitian ini menggunakan mencit jantan dari jenis Mus musculus Outbred Balb/C yang berumur 4 minggu, sebanyak 28 ekor dari Pusvetma Waru-Surabaya. Mencit dipilih yang sehat dengan indikator pada hasil kultur tinja mencit tidak terdapat pertumbuhan $H$. pylori.

Isolasi Protein Hemaglutinin Outer Membrane Protein (OMP) H. pylori

Penelitian ini dikerjakan dalam 2 tahap. Pertama pemisahan pili dan kedua pemisahan OMP. Tahap pertama merujuk metode dari Ehara [14]. Pili dipanen dari 50 botol biakan bakteri. Hasil koleksi bakteri ditambahkan Trichlor Aceticacid (TCA) sampai konsentrasi 3\%. Setelah itu dikocok rata maka diletakkan pada suhu kamar selama satu jam. Selanjutnya dilakukan sentrifugasi $6.000 \mathrm{rpm}$ selama 30 menit suhu $4{ }^{\circ} \mathrm{C}$. Pelet diambil, diresuspensi dengan cairan PBS $\mathrm{pH} \mathrm{7,4} \mathrm{perbandingan} \mathrm{1:10.} \mathrm{Bakteri} \mathrm{dicukur}$ dengan menggunakan mixer yang didesain oleh Laboratorium Politeknik Universitas Brawijaya Malang. Bakteri dicukur dengan kecepatan penuh selama satu menit, diulang sampai 5 kali dengan masa istirahat satu menit. Hasilnya dilakukan sentrifugasi selama 30 menit kece-patan 12.000 rpm suhu $4{ }^{\circ} \mathrm{C}$ selama 30 menit. Pili yang terletak pada bagian supernatan diambil. Endapan disuspensikan dengan larutan dan cara yang sama dan dikumpulkan dengan cara mencukur ulang sampai beberapa kali hingga diperoleh supernatan yang menunjukkan tes aglutinasi negatif. Tahap kedua, isolasi protein hemaglutinin OMP dengan metode modifikasi dari Evan's [15]. Modifikasi dilakukan pada bagian sampel yang digunakan yaitu bagian endapan dari perlakuan pemotongan pili pada putaran yang terakhir. Pelet disuspensikan dengan PBS $\mathrm{pH}$ 7,4 sampai volumenya mencapai 15 kali, kemudian ditambah N-Octyl-B-D-glucopyranoside (NOG) konsentrasi mencapai 0,5\%. Dilakukan homogenisasi dengan vortek kecepatan penuh selama satu menit. Selanjutnya dilakukan sentrifugasi kecepatan $12.000 \mathrm{rpm}$ suhu $4{ }^{\circ} \mathrm{C}$ selama 30 menit. Selanjutnya supernatan diambil dan dilakukan dialisa pada 24 jam pertama dengan mengggunakan $\mathrm{dH}_{2} \mathrm{O}$ dan pada 24 jam kedua dipakai PBS pH 7,4. Perlakuan ini diulangi sampai lima kali. Kemudian dilakukan SDS-PAGE.

Elektroforesis dengan Sodium Dodecyl Silfate Polyacrylamid Gel Electrophoresis (SDS-PAGE)

Sampel protein dipanaskan $100{ }^{\circ} \mathrm{C}$ selama lima menit dalam larutan penyangga yang mengan-dung $5 \mathrm{mM}$ Tris $\mathrm{HCl} \mathrm{pH} 6,8,5 \%$ 2mercapto ethanol, 2,5\% Sodium Dodecyl Sulfate, $10 \%$ glycerol dengan warna pelacak bromophenol blue. Dipilih $10 \%$ mini slab gel dengan tracking gel 4\%. Voltase yang digunakan $125 \mathrm{mV}, 120 \mathrm{~mA}$, selama 130 menit. Sebagai bahan pewarna adalah coomasie brilliant blue dan dipergunakan molekul standar sigma wide range marker dengan menggunakan metode Laemmli dengan modifikasi Winarsih et al. [15].

\section{Coupling OMP H. pylori dengan Cholerae Toxin B (CTB)}

OMP yang dihasilkan kemudian di-coupling dengan Cholerae Toxin B (CTB). Hasil dari coupling OMP $H$. pylori dengan CTB tersebut baru diberikan ke masing-masing mencit perlakuan dengan dosis $100 \mathrm{\mu g} \mathrm{ml}^{-1}$ tiap minggu secara intragastrik dengan menggunakan sonde. 
Sebelum diberi perlakuan, mencit diberi larutan natrium bikarbonat $0,2 \mathrm{M}$ sebanyak $0,3 \mathrm{ml}$ untuk menetralisir asam lambung. Pada akhir minggu ke 2, 4, 6, dan 8 dibandingkan perubahan gambaran histopatologi dan Secretory Immunoglobulin A (S-IgA) antara mencit kontrol dan perlakuan.

Pembuatan Slide Pemeriksaan Patologi Anatomi

Mencit dimatikan pada akhir minggu ke-2, ke-4, ke-6 dan ke-8 kemudian diambil lambungnya dan dibuat sediaan patologi anatomi dan diwarnai dengan pewarnaan hematoksilin eosin. Pengamatan perubahan patologi anatomi lambung dilakukan dengan metode skoring.

Pemeriksaan Kadar Secretory IgA Metode ELISA

Pemeriksaan kadar S-IgA dikerjakan menurut metode Sanarto, yakni dengan memotong usus kemudian dicuci dengan PBS dingin yang mengandung protease inhibitor $\left(25 \mu \mathrm{g} \mathrm{m} \mathrm{m}^{-1}\right.$ inhibitor cocktail) dan 1,0 mM EDTA. Lapisan mukus diambil dengan cara scraping secara longitudinal menggunakan spatel dan ditampung di dalam tabung yang berisi PBS steril dan protease inhibitor. Suspensi dikocok kemudian disentrifugasi $12.000 \mathrm{rpm}$ pada $4{ }^{\circ} \mathrm{C}$ selama 10 menit. Supernatan diambil dan digunakan sebagai sampel mukus untuk pemeriksaan S-IgA dengan metode ELISA [10].

Pemeriksaan ELISA dilakukan dengan metode Harlow and Lane. Tahap pertama adalah dimasukkan antigen OMP H. pylori $100 \mu \mathrm{l}$ dalam sumuran lempeng mikrotiter untuk ELISA, diinkubasi semalam pada suhu $4{ }^{\circ} \mathrm{C}$. Kemudian sumur dicuci dua kali dengan washing solution (larutan PBS yang mengandung 0,05\% Tween20). Ditambahkan larutan $1 \%$ Bovine Serum Albumin (BSA) di dalam PBS dan diinkubasi pada suhu $37{ }^{\circ} \mathrm{C}$ selama satu jam. Sumur dicuci sebanyak dua kali dengan washing solution. Selanjutnya ditambahkan antibodi primer yang berasal dari mukus sebanyak $100 \mu \mathrm{l}$. Campuran diinkubasi pada suhu $37{ }^{\circ} \mathrm{C}$ selama dua jam. Sumuran dicuci sebanyak dua kali dengan washing solution dan ditambahkan antibodi sekunder (konjugat anti IgA mencit yang dilabel enzim alkali-phosphatase) sebanyak $100 \mu \mathrm{l}$, dilakukan inkubasi pada suhu $37{ }^{\circ} \mathrm{C}$ selama satu jam. Sumur dicuci sebanyak dua kali menggunakan washing solution. Kemudian ditambahkan larutan substrat (campuran p-nitrophenylphosphat, diethanol amine dan $\mathrm{MgCl}_{2}$ ) sebanyak $100 \mu \mathrm{l}$, diinkubasi pada suhu $37{ }^{\circ} \mathrm{C}$ selama satu jam. Setelah terlihat warna kuning, ditambahkan stop solution (3M NaOH) dan segera diamati
Optical Density (OD) larutan pada panjang gelombang $405 \mathrm{~nm}$ menggunakan ELISA reader.

\section{Analisa Data}

Data yang diperoleh ditabulasi sesuai dengan kelompok perlakuan kemudian dianalisa dengan analisa sidik ragam satu arah (Oneway ANOVA) dan Uji Tukey.

\section{HASIL DAN PEMBAHASAN}

Elektroforesis dengan Sodium Dodecyl Silfate Polyacrylamid Gel Electrophoresis (SDS-PAGE)

Hasil elektroforesis OMP H. pylori dan marker dengan menggunakan metode SDS-PAGE, diperoleh data seperti pada Gambar 1. Hasil pengukuran pita protein pada OMP $H$. pylori diperoleh berat molekul protein pada kisaran $12,78 \mathrm{kDa}$, 24,01 kDa, 27,25 kDa, 36,099 kDa, 41,067 kDa, 44,52 kDa, 58,10 kDa, 63,87 kDa dan 68,02 kDa. Winarsih et al., menemukan bahwa telah ditemukan protein hemaglutinin $32 \mathrm{kDa}$ dan protein $20 \mathrm{kDa}$ adalah cell surface associated dan merupakan faktor adhesi pada $H$. pylori galur lokal HP7M [16]. Peck menemukan bahwa protein 48 kDa disebut HopA (Helicobacter pylori Outer Membrane Protein A), 49 kDa disebut HopB, 50 kDa disebut HopC, 67 kDa disebut HopD dan 31 kDa disebut HopE [17]. O'Toole mengemukakan bahwa protein yang terdapat pada outer membrane dan berperan sebagai faktor adhesi adalah HopZ (74,2 kDa), BabA (80,6 kDa), AlpA (56,4 kDa) dan AlpB (56,7 kDa) [18].

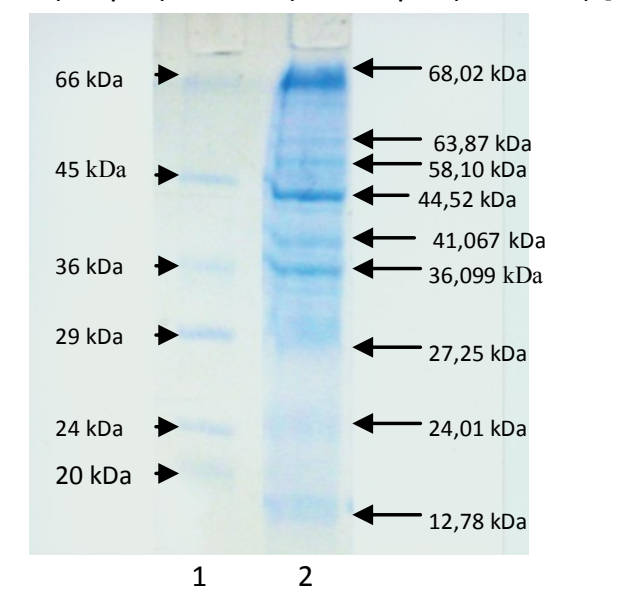

b

c

e

$f$

g

$\mathrm{h}$

i

Gambar 1. Hasil elektroforesis OMP H.pylori dengan metode SDS-PAGE.

Keterangan:

1. Marker (Protein perunut)

2. OMP H.pylori

Analisis histopatologi pada lambung hewan coba pasca pemaparan OMP $H$. pylori dengan menggunakan pewarnaan Hematoksilin Eosin. Pengaruh pemaparan dengan OMP $H$. pylori pada hewan model menunjukkan kondisi 
histologi lambung diperoleh data seperti pada Gambar 2.

Menurut modifikasi Humphreys, gambaran histopatologi berdasarkan tingkat peradangan pada mukosa lambung Mus musculus Outbred Balb/C normal (Gambar 2A dan 2C) mempunyai skor 0 (nol) yaitu epitel dalam batas normal, asinus kelenjar dalam batas normal, sebukan sel radang sangat minimal, pada kelompok yang dipapar OMP mempunyai skor histopatologis 0 (Gambar 2B) dan 1 pada kelompok 2 (Gambar 2D).

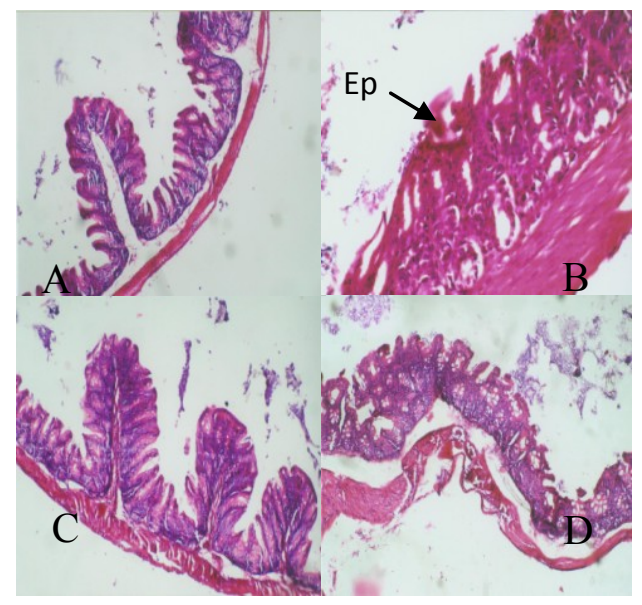

Gambar 2. Potongan lambung Mus musculus Outbred Balb/C kelompok 1 dan 2 dengan pewarnaan hematoxilin eosin, perbesaran 100 kali.

Keterangan:

A. lambung Mus musculus Outbred Balb/C kontrol

B. lambung Mus musculus Outbred Balb/C yang dipapar OMP H. Pylori

C. lambung Mus musculus Outbred Balb/C kontrol

D. lambung Mus musculus Outbred Balb/C yang dipapar OMP H. Pylori

\section{Pemeriksaan Histopatologis}

Menurut modifikasi Humphreys, gambaran histopatologi berdasarkan tingkat peradangan pada mukosa lambung Mus musculus Outbred Balb/C normal pada kelompok 3 dan 4 (Gambar 3A dan 3C) mempunyai skor 0 (nol) sampai satu yaitu epitel dalam batas normal, asinus kelenjar dalam batas normal, sebukan sel radang minimal berjumlah 0 (nol) sampai lima, pada kelompok yang dipapar OMP, pada kelompok 3 (Gambar 3B) mempunyai skor histopatologis 2 sampai 3, pada bagian ini mulai terlihat epitel sebagian terkelupas, asinus kelenjar mengalami vakuolisasi, edema di antara jaringan periglandular dan sebukan sel radang berjumlah 8 sampai 10 . Pada kelompok 4, (Gambar 3D) skor histopatologis yang ditemukan adalah 3 sampai 4 , disini terlihat epitel sebagian terkelupas, asinus kelenjar mengalami vakuolisasi dan atrofi, sebukan sel radang bertambah yaitu lebih dari 10 .

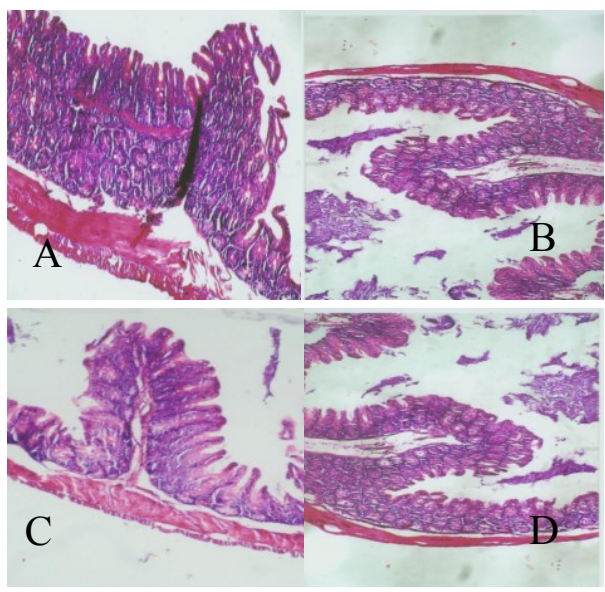

Gambar 3. Potongan lambung Mus musculus Outbred Balb/C kelompok 3 dan 4 dengan pewarnaan hematoksilin eosin.

Keterangan:

A dan $C$ adalah lambung Mus musculus Outbred Balb/C kontrol sedangkan B dan D adalah lambung Mus musculus Outbred Balb/C yang dipapar OMP $H$. pylori. A,C,D perbesaran 100 kali, B perbesaran 400 kali.

\section{Pemeriksaan Patologi Anatomi (Skor Histopatologis)}

Hasil analisa mengenai perbandingan skor histopatologis, antara kontrol dan perlakuan dapat dilihat pada Gambar 4.

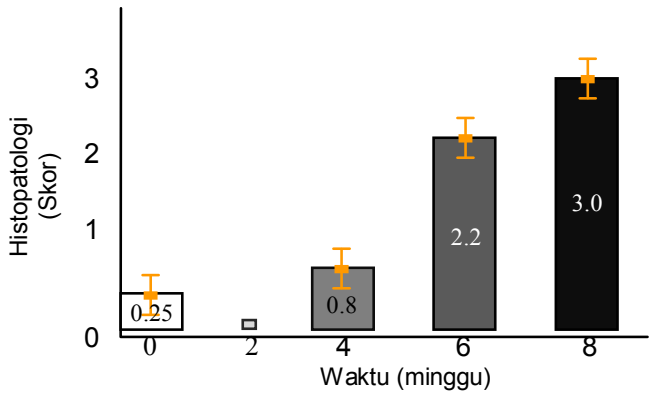

Gambar 4. Skor kerusakan histologi kontrol dan perlakuan Keterangan :

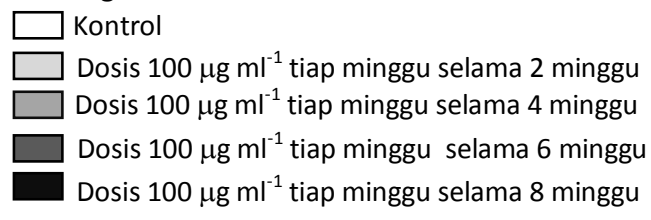

Pada Gambar 4, diperoleh rerata skor histopatologis pada kelompok perlakuan lebih tinggi dibandingkan kelompok kontrol dan yang paling tinggi pada kelompok perlakuan yang dipapar OMP H. pylori $100 \mu \mathrm{g} \mathrm{ml}^{-1}$ tiap minggu 
selama 8 minggu. Semakin lama pemaparan dengan OMP $H$. pylori maka semakin berat kerusakan mukosa lambung yang terjadi. Hasil analisis statistika ANOVA menunjukkan adanya perbedaan secara signifikan $(\mathrm{P}<0.05)$ skor histopatologis antara kontrol dan perlakuan. Hasil uji lanjut Tukey menunjukkan adanya perbedaan secara signifikan $(P<0.05)$ antara kelompok kontrol dengan perlakuan. Hal ini disebabkan pada kelompok perlakuan, OMP H. pylori merusak mukosa lambung (gaster) mencit sedangkan pada kontrol tidak terdapat kerusakan. Hal ini dapat dijelaskan karena di dalam outer membrane protein $H$. pylori Phospholipase A (OMP-A) yang dilibatkan dalam virulensi dari strain Campylobacter dan Helicobacter [19].

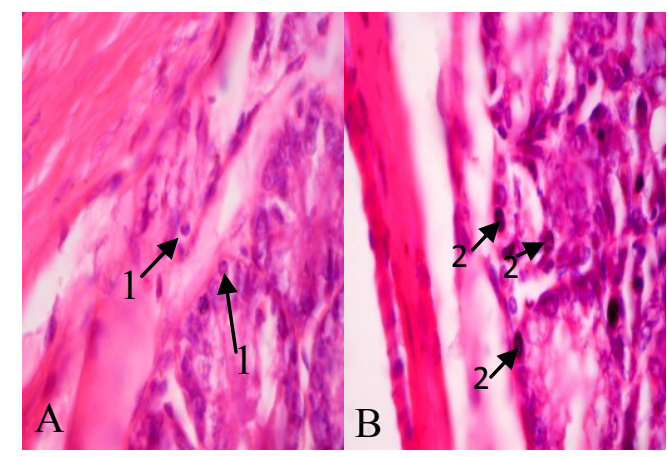

Gambar 5. Sel-sel PMN dan MN dalam sediaan potongan lambung Mus musculus Outbred Balb/C kelompok 2 (A) dan kelompok 4 (B) dengan pewarnaan haematoksilin eosin, perbesaran 1000 kali. Tanda panah menunjukkan sel PMN (1) dan sel MN (2).

\section{Jumlah Sel-Sel Polimorfonuclear (PMN)}

Histologi sel PMN dan MN pada lambung Mus musculus Outbred Balb/C kelompok 2 (A) dan kelompok 4 (B) dengan pewarnaan haematoksilin eosin dapat dilihat pada Gambar 5. Hasil perhitungan mengenai perbandingan jumlah PMN antara kontrol dan perlakuan yang dipapar dengan menggunakan OMP $H$. pylori diperoleh data yang dapat dilihat pada Gambar 6. Pada Gambar 6, diperoleh rerata jumlah sel polimorfonuklear (PMN) pada kelompok perlakuan yang dipapar OMP H. pylori $100 \mu \mathrm{g} \mathrm{ml}^{-1}$ tiap minggu selama 4 minggu yaitu kelompok perlakuan yang dimatikan pada akhir minggu ke4 lebih tinggi dibandingkan kelompok kontrol dan kelompok perlakuan lainnya. Jadi semakin lama pemaparan dengan OMP $H$. pylori maka jumlah PMN semakin rendah. Hasil analisa statistika menggunakan ANOVa, diketahui terdapat perbedaan yang signifikan terhadap rerata jumlah PMN antara kontrol dan perlakuan $(p<0,05)$. Uji lanjutan Tukey menunjukkan bahwa terdapat perbedaan secara nyata terjadi pada kelompok kontrol dan perlakuan. Hal ini dapat dijelaskan karena sel polimorfonuklear merupakan sel-sel radang akut jadi meningkat pada keadaan infeksi akut sedangkan pada minggu ke- 8 jumlah sel menurun.

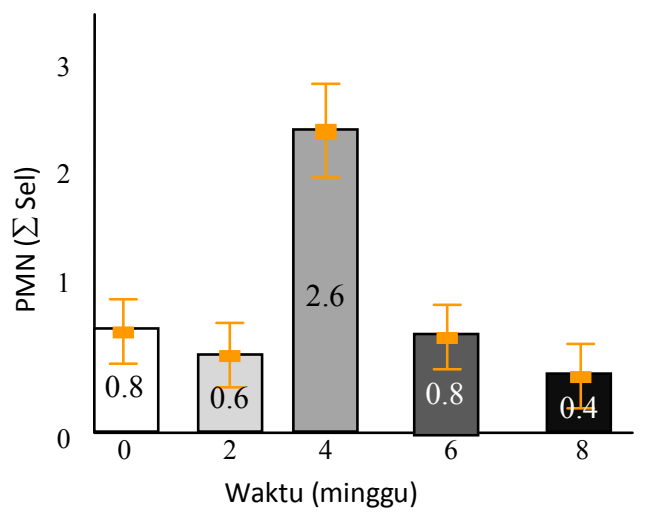

Gambar 6. Perbandingan Jumlah MPN pada kontrol dan perlakuan

Keterangan :

Kontrol

Dosis $100 \mu \mathrm{g} \mathrm{ml}^{-1}$ tiap minggu selama 2 minggu

Dosis $100 \mu \mathrm{g} \mathrm{ml}^{-1}$ tiap minggu selama 4 minggu

$\square$ Dosis $100 \mu \mathrm{g} \mathrm{ml}^{-1}$ tiap minggu selama 6 minggu

Dosis $100 \mu \mathrm{g} \mathrm{ml}^{-1}$ tiap minggu selama 8 minggu

\section{Jumlah Sel-Sel Mononuklear (MN)}

Hasil pengamatan jumlah sel-sel mononuklear pada kelompok kontrol dan perlakuan dengan metode skoring histopatologi sel-sel mononuklear diperoleh data seperti pada Gambar 7. Pada Gambar 7, menunjukkan ratarata jumlah sel Mononuklear (MN) pada kelompok perlakuan lebih tinggi dibandingkan kelompok kontrol dan yang paling tinggi pada kelompok perlakuan yang dipapar OMP H. Pylori $100 \mathrm{\mu gml}^{-1}$ setiap minggu selama 8 minggu yaitu kelompok perlakuan yang dimatikan pada akhir minggu ke-8. Jadi semakin lama pemaparan dengan OMP H. pylori maka jumlah sel MN akan semakin meningkat. Hasil analisa statistik menggunakan ANOVA memperlihatkan adanya perbedaan secara signifikan $(P<0.05)$ rerata jumlah $\mathrm{MN}$ antara kontrol dan perlakuan $(p<0,05)$. Analisa lanjutan Tukey memperlihatkan perbedaan yang signifikan antara kontrol dan perlakuan. Hal ini dimungkinkan karena sel mononuklear merupakan sel-sel radang kronik sehingga berpotensi meningkat pada infeksi kronik. $H$. pylori dapat berikatan kuat dengan sel epitel dengan menggunakan komponen permukaan bakteri yang multipel yang dikenal 
secara khusus sebagai adhesin, BabA adalah outer membrane protein $78 \mathrm{kD}$ yang berikatan ke fucosylated Lewis $B$ blood-group antigen. Terutama BabA relevan dengan penyakit yang berhubungan dengan $H$. pylori dan diduga dapat mempengaruhi tingkat keganasan penyakit [6].

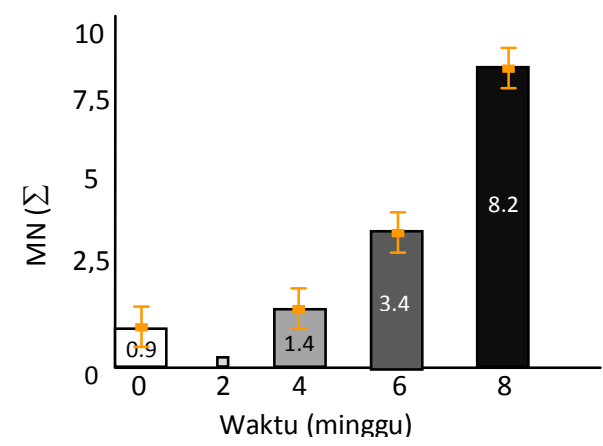

Gambar 7. Perbandingan jumlah MN antara kontrol dan perlakuan

Keterangan :

\section{Kontrol}

Dosis $100 \mu \mathrm{g} \mathrm{ml}^{-1}$ tiap minggu selama 2 minggu

Dosis $100 \mu \mathrm{g} \mathrm{ml}^{-1}$ tiap minggu selama 4 minggu

Dosis $100 \mu \mathrm{g} \mathrm{ml}^{-1}$ tiap minggu selama 6 minggu

Dosis $100 \mu \mathrm{g} \mathrm{ml}^{-1}$ tiap minggu selama 8 minggu

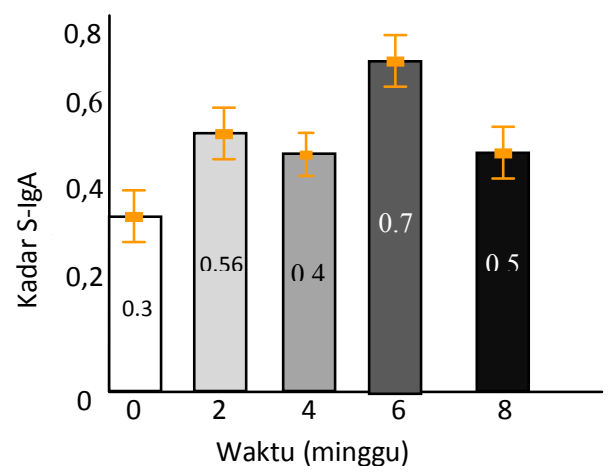

Gambar 8. Perbandingan kadar S-IgA antara kontrol dan perlakuan

Keterangan :

\section{Kontrol}

Dosis $100 \mu \mathrm{g} \mathrm{ml}^{-1}$ tiap minggu selama 2 minggu

Dosis $100 \mu \mathrm{g} \mathrm{ml}^{-1}$ tiap minggu selama 4 minggu

Dosis $100 \mathrm{gg} \mathrm{ml}^{-1}$ tiap minggu selama 6 minggu

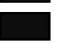

Dosis $100 \mu \mathrm{g} \mathrm{ml}^{-1}$ tiap minggu selama 8 minggu

\section{Hasil Pemeriksaan S-IgA}

Hasil pemeriksaan kadar S-IgA antara kelompok kontrol dan perlakuan dengan menggunakan metode ELISA diperoleh data seperti pada Gambar 8. Hasil penelitian pada Gambar 8, diperoleh rerata kadar Secretory IgA pada kelompok perlakuan lebih tinggi dibandingkan kelompok kontrol dan yang paling tinggi pada kelompok mencit perlakuan yang dipapar
OMP $H$. pylori $100 \mu \mathrm{g} \mathrm{ml}^{-1}$ tiap minggu selama 6 minggu. Hasil analisis statistik menggunakan ANOVA memperlihatkan adanya perbedaan secara signifikan $(\mathrm{P}<0.05)$ rerata kadar $\mathrm{S}$-IgA antara kontrol dan perlakuan $(p<0,05)$. Kadar Secretory Ig-A dari keempat kelompok perlakuan juga meningkat secara signifikan pada kelompok perlakuan yang dipapar OMP dibandingkan kelompok kontrol. Efek pro-tektif S-IgA dalam lumen saluran cerna diketahui berfungsi untuk menetralisir secara biologi antigen aktif seperti proteksi terhadap toksin dan virus dengan membentuk kompleks imun intraluminal dan kemampuan S-IgA untuk melapisi bakteri sehingga dapat mencegah perlekatan sel bakteri ke epitel [20].

Peran antibodi humoral dalam gastritis masih belum jelas. Penelitian menunjukkan bahwa bakteri-bakteri yang melekat pada epitel lambung diliputi oleh S-IgA, tetapi antibodi tersebut bersifat tidak efektif dalam membunuh bakteri atau mencegah adhesi bakteri pada epitel lambung [8]. Pada penelitian sebelumnya dijelaskan bahwa kadar S-IgA yang tinggi juga dapat berpotensi merusak sel mukosa pada organ lambung. Menurut Goto, antibodi lokal SIgA berperan utama dalam proteksi terhadap infeksi H. Pylori [11]. Beberapa peneliti berpendapat bahwa vaksinasi oral dengan antigen whole-cell $H$. pylori atau antigen yang dipurifikasi dapat mencegah infeksi dari spesies Helicobacter. Vaksinasi oral dengan dosis lebih besar dari $200 \mu \mathrm{g} \mathrm{H}$. pylori whole-cell sonicate selama lima minggu efektif melindungi mencit 57BL terhadap infeksi bakteri $H$. pylori [21]. Pada penelitian ini dipergunakan dosis $100 \mathrm{\mu g} \mathrm{ml}^{-1}$ tiap minggu dengan lama waktu pemberian 2, 4, 6 dan 8 minggu. Pada penelitian ini diketahui bahwa perubahan histopatologis yang mulai terlihat setelah pemberian dosis $100 \mathrm{gg} \mathrm{I}^{-1}$ tiap minggu dalam 6 minggu dan dosis $100 \mu \mathrm{g}^{-1}$ tiap minggu dalam 8 minggu, sama dengan hasil dari penelitian di atas. Czinn, mengemukakan bahwa terjadi peningkatan kadar S-IgA pada lambung mencit pasca dipapar dengan H. Pylori [22]. Pernyataan tersebut memberikan hasil yang sama dengan penelitian ini yaitu OMP $H$. pylori yang diberikan secara intragastrik pada mencit juga meningkatkan kadar S-IgA.

\section{KESIMPULAN}

Protein OMP H. pylori adalah $12,78 \mathrm{kDa}$, 24,01 kDa, 27,25 kDa, 36,099 kDa, 41,067 kDa dan 44,52 kDa, 58,10 kDa, 63,87 kDa dan 68,02 kDa berpotensi menimbulkan kerusakan pada 
mukosa lambung Mus musculus Outbred Balb/C. Semakin lama pemaparan dengan OMP H. pylori dengan dosis yang sama pada hewan coba maka semakin berat kerusakan mukosa lambung yang terjadi. Protein OMP H. pylori 12,78 kDa, 24,01 $\mathrm{kDa}, 27,25 \mathrm{kDa}, 36,099 \mathrm{kDa}, 41,067 \mathrm{kDa}$ dan 44,52 kDa, 58,10 kDa, 63,87 kDa dan 68,02 kDa dapat menginduksi peningkatan S-IgA pada Mus musculus Outbred Balb/C.

\section{DAFTAR PUSTAKA}

1. Prescott, L.M., A.K. Donald, P.H. John. 2002. Microbiology $5^{\text {th }}$ edition. Mc Graw Hill Company. New York.

2. Lee, A. 1999. Animal Models of Helicobacter Infection. Molecular Medicine. 5:500-505.

3. Mach, F. 2002. Influence of Helicobacter pylori Infection During Atherogenesis In Vivo in Mice. Circulation Respiration. 90:e1-e4.

4. Keenan, J., T. Day, S. Neal, B. Cook, G. PerezPerez, R. Allardyce, P. Bagshaw. 2000. A Role for The Bacterial Membrane in The Pathogenesis of Helicobacter pylori Infection. FEMS Microbiol. Lett. 182:259-264.

5. Enders, K.W.NG., S.A. Thompson, G.I. Perez, I. Kansau, V.D.E.A Arie, Labigne, J.J.Y. Sung, S.C.S. Chung, M.J. Blaser. 1999. Helicobacter pylori Heat Shock Protein A: Serologic Responses and Genetic Diversity. Clin. And Diagn. Lab. Immunology. Vol.6. No. 3:377382.

6. Suerbaum, S., M. Pierre. 2002. Helicobacter pylori Infection. N. Engl. J. Med. 347. 15:11751186.

7. Kawahara, T., Y. Yokota, K. Mizuno. 1999. Antibodies to Human Gastric Epithelial Cells and Heat Shock Protein 60 in Helicobacter pylori Positie Mucsa Associated Lymphoid tissue Lymphoma. 45:20-23.

8. Harijono, A. 1996. Peran Stresor pada Imun Mukosa dalam Patogenesis Gastritis Kronik karena Helicobacter pylori. Disertasi. Program Pasca-sarjana Universitas Airlangga. Surabaya.

9. Harijono, A. 2002. Aspek Sero Epidemiologi Helicobacter pylori di Indonesia dan di Dunia, Patogenesis dan Respon Penjamu pada Infeksi Helicobacter pylori dalam $4^{\text {th }}$ Course on Immunology: Tropical Infectious Disease. Universitas Gajah Mada. Yogyakarta.

10. Sanarto, S. 2002. Protein Adhesin Salmonella typhi sebagai Faktor Virulensi Berpotensi Imunogenik pada Produksi S-IgA Protektif. Disertasi. Program Pascasarjana Universitas Airlangga. Surabaya.
11. Brooks, G.F., S.B. Janet, Morse, A. Stephen. 2001. Vibrios, Campylobacter, Helicobacter, and Associated Bacteria in: Jawetz, Melnick, Adelberg's. Medical Microbiology. $22^{\text {nd }}$ Edition. Lange Medical Books. Mc Graw-Hill. New York.

12. Bratawidjaya, K.G. 2001. Immunologi Dasar. Balai Penerbit Fakultas Kedokteran Universitas Indonesia. Jakarta.

13. Abbas, A.K., A.H. Lichtman, Pober, Jordan. 2000. Cellular and Molecular Immunology, $4^{\text {th }}$ edition. W.B. Saunders Company. Pennsylvania.

14. Ehara, M., M. Ishibashi, Y. Ichinose, $M$. Iwanaga, S. Shimotori, T. Naito. 1987. Purification and Partial Characterization of Pili of Vibrio cholerae 01. Vaccine. 5:283-288.

15. Sumarno. 2000. Karakterisasi Molekuler Protein Adesi Vibrio cholerae 01 M094V dan Protein Reseptornya pada Sel Epitel Usus Halus Tikus Putih (Wistar). Studi Patogenesis Vibrio cholerae 01 M094V. Tesis. Program Pascasarjana Universitas Airlangga. Surabaya.

16. Winarsih, S., Sumarno, Roekistiningsih. 1997. Fungsi dan Sifat imunogenitas Protein Hemaglutinin 32 KD dan 20 KD pada Helicobacter pylori. Majalah Kedokteran Universitas Brawijaya. vol. XIII. No. 3:135-141.

17. Peck, B. 1999. Conservation, Localization and Expression of HopZ, a protein involved in adhesion of Helicobacter pylori. Nucleic Acid Research. 27. 16:3325-3333.

18. O'Toole, P.W., M. Clyne. 2001. Cell Envelope dalam Mobley, H.L.T., G.L. Mendz, S.L. Hazell., Helycobacter pylori: physiology and Genetics. ASM Press. New York.

19. Koebnik, R., Locher, P. Kaspar, P. Gelder. 2000. Micro review: Structure and Function of Bacterial Outer Membrane Proteins : Barrels in a Nutshell. Molecular Microbiology. 37. 2:239-253.

20. Mestecky, J., P. N. Fultz. 1999. HIV-1 Infection, Mucosal Immunity and Pathogenesis. Mucosal Immune System of The Human Genital Tract. Vol.179. Supplement 3:S470-S474.

21. Goto, T., K. Haruma, Y. Kitadai, M. Ito, M. Yoshihara, K. Sumii, N. Hayakawa, G. Kajiyama. 1999. Enhanced Expression of Inducible Nitric Oxide Synthase and Nitrotyrosine in Gastric Mucosa of gastric Cancer Patient. Clin cancer Res 5:1411-1415.

22. Ciznn, S. J., J.G. Nedrud. 1991. Oral Immunization Against Helicobacter pylori. Infection and Immunity. July. 2359-2363. 